\title{
28 Resarch Square \\ Hydrochemistry of sediment pore water in the Bratsk reservoir (Baikal region, Russia)
}

\section{Vera Poletaeva ( $\nabla$ alieva@igc.irk.ru )}

Vinogradov Institute of Geochemistry

\section{Elvira Tirskikh}

Vinogradov Institute of Geochemistry

Mikhail Pastukhov

Vinogradov Institute of Geochemistry

\section{Research Article}

Keywords: sediment pore water, reservoir, major ions, geochemistry

Posted Date: December 1st, 2020

DOI: https://doi.org/10.21203/rs.3.rs-114930/v1

License: @ (i) This work is licensed under a Creative Commons Attribution 4.0 International License. Read Full License 


\section{Abstract}

This study was aimed at identifying the processes responsible for the major ion composition of pore water from the bottom sediments of the Bratsk water reservoir, which is a part of the largest freshwater Baikal-Angara water system. The pore water ionic composition varies both along the sediment depth profile and across the water area. In pore water, the difference between the highest and lowest values is remarkably large: 5.1 times for $\mathrm{K}+$, 13 times for $\mathrm{Mg} 2+, 16$ times for HCO3-, 20 times for $\mathrm{Ca} 2+, 23$ times for $\mathrm{Na}+, 80$ times for SO42-, 105 times for $\mathrm{Cl}$. Such a variability suggests that the dominant factors, influencing pore water chemistry, depend on the location. At the first stages of the sedimentation process, the chemistry of the pore water in the Bratsk reservoir is dependent on $\mathrm{HCO}-\mathrm{Ca}$ of the overlying water. Later on, due to the interaction with the sedimentary terrigenous material, they changed to $\mathrm{SO} 4, \mathrm{SO} 4-\mathrm{HCO} 3, \mathrm{HCO}-\mathrm{SO} 4, \mathrm{HCO} 3-\mathrm{Cl}-\mathrm{SO} 4$-water types with exchangeable cations, mainly $\mathrm{Ca}$. Some of pore waters may have a complex genesis associated with subaqueous groundwater discharge. The change in the redox potential observed in the pore water is the indicator of earlydiagenetic transformations taking place in bottom sediments.

\section{Introduction}

In contrast to natural water, reservoir basins are specific ecosystems, formed under the influence of both natural and technogenic factors, which leads to irreversible changes in their hydrological, hydrochemical and hydrobiological regimes $[1,2]$. The addition of technogenic organic and inorganic matter, which enter the reservoir with wastewater, surface runoff and through the atmospheric deposition from contaminated areas, could bring about even more undesirable negative changes $[3,4]$. Similar to a natural pool, biogeochemical cycles in the reservoir are defined by a constant interaction between abiotic and biotic components of the biosphere. However, water flow slowdown and changes in sedimentation conditions after the river flow regulation $[5,6]$ forms new ecosystem, in which the migration behavior of elements will significantly change. In aquatic ecosystems, element geochemical cycles can be better understood through studies of chemical composition of the pore water that fills spaces between solid particles of bottom sediments $[7,8]$. Elemental composition of the pore water trapped in sediments can be used to study the conditions of matter circulation and its exchange between the bottom sediments and overlying water $[9,10]$. Pore water chemistry has proved to be a sensitive indicator for diagenetic transformations of bottom sediments even when changes in their chemical characteristics may not be noticeable [11]. As was shown earlier, the initial composition of the pore water trapped in sediments is affected by a number of factors like cation exchange reactions between the pore water and bottom sediments, $\mathrm{pH}$ and redox potential values and role of pore water in the formation of minerals [12].

Freshwater ecosystems are the most vulnerable to man-made impacts [13]. The Baikal-Angara water system, that includes Lake Baikal and the Angara River, the only channel of the lake's surface runoff, is estimated to have the largest supply of fresh low-mineralized water in the world. Its resources are widely used for different purposes such as drinking, household, and industrial water supply in large cities and small settlements located on its shores. At the same time, the water body of the Angara river is a subject to huge impact due to the construction of a series of water reservoirs (Irkutsk, Bratsk, Ust-llimsk, Boguchansk), that drastically changed the ecosystem of the river. The technogenic substances entering the Angara River and its water reservoirs were found to affect the chemical composition of abiotic and biotic components $[14,15]$. Amongst the cascade 
reservoirs, the Bratsk, the second of the cascade, whose filling was completed in 1967, is considered the most technogenically-stressed. Despite there is great amount of information concerning the elemental composition of water [16-18], bottom sediments [19, 20] and biota [21] of the Bratsk reservoir, yet, the pore water chemistry remains an insufficiently studied geochemical sector. The pore water studies, done in 1980ies, the initial period of the reservoir operation [22], included only the determination of main cations $\left(\mathrm{Na}^{+}, \mathrm{K}^{+}, \mathrm{Ca}^{2+}, \mathrm{Mg}^{2+}\right)$ and biogenic components $\left(\mathrm{NO}_{3}{ }^{-}, \mathrm{SiO}_{2}{ }^{-}, \mathrm{PO}_{4}{ }^{3-}\right)$ in the pore solution. Since the data on the chemical composition of the pore water from sediments accumulated in the Bratsk reservoir over a 50-year operation period is very scarce, it is difficult to describe geochemical cycling in its ecosystem. Therefore, the main aims of the present study were i) to determine concentrations of major ions in the sediment pore water; and ii) to study the factors affecting the pore water chemistry. As sedimentation conditions and factors influencing the geochemical environment in artificial reservoirs are different from those of natural basins, the study of sediment pore water in the Bratsk Reservoir is of particular relevance, given the possibility to apply the obtained results and conclusions to other large reservoirs.

\section{Research area}

The Bratsk reservoir, a result of damming the Angara River due to the construction of the Bratsk Hydroelectric Plant, is located in the Baikal region, Russia (Fig. 1). It is one of the largest reservoirs in the world: its full storage capacity approximates $170 \mathrm{~km}^{3}$, the water surface area is equal to $5470 \mathrm{~km}^{2}$, the length is over $500 \mathrm{~km}$, the maximum depth exceeds $150 \mathrm{~m}$ and the maximum width is $25 \mathrm{~km}$. The intra-annual water level fluctuations over the period of many years do not exceed 2-3 m. However, in prolonged low-water periods, the amplitude of water level fluctuations can be as high as $10 \mathrm{~m}$ [23]. The rate of surface water flow is typically $1 \mathrm{~m} / \mathrm{s}$; in some locations at a greater depth, it does not exceed $1 \mathrm{~mm} \mathrm{~s}^{-1}$.

The water inflow into the Bratsk reservoir is dominated by the surface inflow, which is generated from water input passing through the Irkutsk Hydroelectric Plant, located upstream, and a lateral inflow. At the gate of the Bratsk Hydroelectric Power Plant, the share of the Baikal runoff is $62 \%$ [23]. When rivers and streams flow into the reservoir, they form numerous bays, therefore creating a highly indented coastline. According to hydrological conditions in the reservoir, variable (from Usolie-Sibirskoe town to Svirsk town) and permanent (downstream Svirsk town) backwater effect zones can be recognized.

In the Bratsk Reservoir, the deposition of sediments is particularly, intense in 10-15 km upstream Svirsk town due to the decrease in the flow velocity, when streamflow is impounded in the reservoir [24]. The thickest deposits of silty material are found on the former riverbed of the Angara River, in $10 \mathrm{~km}$ downstream Svirsk town (Konny Island). The thickness of the sediments decreases further downstream. The principal sediment-forming sources in the reservoir are products of shore abrasion, erosion of coastal cliffs, landslides and solid runoff of tributaries [25]. It has been established that the bottom sediments in the Bratsk reservoir are, primarily, the products of abrasion and erosion of shoreline, which result in a vertical belt zoning determined by sedimentation conditions, including petrographic and lithological-geochemical composition of the rocks from the water drainage area [26]. Annually, about $220 \mathrm{mln}$. tons of sedimentary material is brought into the reservoir due to the shore abrasion, which makes up about $97 \%$ of the total input [26]. 
The reservoir lies along the southern part of the middle Siberian plateau in meridional direction from south to north. The area under study is mainly composed of Lower Cambrian gypsum-carbonate-salt-bearing, Lower Paleozoic red-colored terrigenous-carbonate and Upper Paleozoic-Mesozoic coal-bearing terrigenous formations, which constitute the sedimentary cover of the southern Siberian platform (Fig. 1). The thickness of the Quaternary deposits is insignificant. They overlap the between-river massifs, and fill up river valleys, shores, and floor of folds. The most common soils here are podzolic, sod-podzolic, gray forest and chernozems [22].

In terms of hydrogeology, the area under study is part of the Angara-Lena artesian basin. In the area, there are several aquifers: groundwater in Quaternary sediments, fissure-stratal groundwater associated with the Jurassic, Silurian, Ordovician and Cambrian rocks, and karst-fissure water in the Cambrian gypsum and carbonate rocks [25]. Feeding sources for groundwater are atmospheric precipitation and water inflow from faults and cracks.

\section{Methods}

Taking into account different sedimentation conditions, the chemical composition of the pore water was studied in sediment retrieved from 12 sampling locations throughout the Bratsk reservoir (from Svirsk town to Atalanka settlement (Fig. 1, Table 1). The overlying water (totally 50 samples) was collected from the board of a research vessel using an Ocean Test 110A bathometer from two horizons: surface (from a depth of $0.6 \mathrm{~m}$ ) and bottom (in a meter layer from the bottom). The overlying water samples were taken from the stations lying from UsolieSibirskoe town to Atalanka settlement. Sediment cores were sampled using a gravity sampler (GOIN, Russia) with plastic tubes of $1 \mathrm{~m}$ length. At seven locations, the sediment cores taken contained subaqueous soil. The sediment core for Eh and $\mathrm{pH}$ measurements in the sediment pore water was collected with a plastic tube with side holes for inserting electrodes. In all collected cores, the uppermost sediments (0.5-1 cm thick layer) were brown-orange. The underlying sediments included dark gray, sometimes almost black silts. Depending on the core thickness, the sediment cores were sliced into segments (from 6 to $25 \mathrm{~cm}$ long).

Table 1. Characterization of sediments and pore water sampling sites.

\begin{tabular}{|c|c|c|c|c|c|}
\hline $\begin{array}{l}\text { Sampling } \\
\text { site }\end{array}$ & Location & $\begin{array}{l}\text { Thickness of } \\
\text { sediments } \\
\text { (soil layer } \\
\text { thickness), cm }\end{array}$ & $\begin{array}{l}\text { Sampling } \\
\text { site }\end{array}$ & Location & $\begin{array}{l}\text { Thickness of } \\
\text { sediments } \\
\text { (soil layer } \\
\text { thickness), cm }\end{array}$ \\
\hline B-1 & $\begin{array}{l}3 \mathrm{~km} \text { upstream } \\
\text { Svirsk town }\end{array}$ & 30 & B-7 & $\begin{array}{l}\text { Between Kada and } \\
\text { Uda bays }\end{array}$ & $7(9)$ \\
\hline B-2 & $\begin{array}{l}1 \mathrm{~km} \text { downstream } \\
\text { Svirsk town }\end{array}$ & 41 & B-8 & $\begin{array}{l}\text { Atalanka } \\
\text { settlement }\end{array}$ & $14(18)$ \\
\hline B-3 & Konny Island & 86 & Z-1 & Entry to Osa bay & $26(20)$ \\
\hline B-4 & Bykovo settlement & 20 & $\mathrm{Z}-2$ & Entry to Unga bay & $32(10)$ \\
\hline B-5 & Mol'ka settlement & $17(17)$ & Z-3 & Tal'kino bay & $20(50)$ \\
\hline$B-6$ & Igzhei settlement & 17 & Z-4 & Kada bay & $16(8)$ \\
\hline
\end{tabular}


The $\mathrm{pH}$ and redox potential (Eh) of overlying water were measured in situ using an Eh/pH meter (HANNA HI98121), which features $0.01 \mathrm{pH}$ and $1 \mathrm{mv}$ Eh resolution. The $\mathrm{pH}$ of the sediment pore water was defined using Expert-001, Russia pH/Eh meter having pH-electrode ESK-10616 with $0.01 \mathrm{pH}$ resolution. The Eh was measured in moist dark-grey sediments using Expert-001 pH/Eh meter with Eh-electrode EPR-105, 1mV Eh resolution.

The pore water was extracted from the sediments by the centrifugation using a laboratory centrifuge (Beckman) with a rotor mounted in a horizontal plane. The centrifugation was carried out at a speed of 3000 RPM for 30 minutes.

The major ions in water samples were determined at the Center for Collective Use "Isotope-Geochemical Research" of the IGC SB RAS (Irkutsk, Russia). The analysis was performed in accordance with a standard certified analytical quality control procedure. Reagent blanks and certified reference materials were used to control the analytical accuracy. Flame emission spectrophotometry was used in the analysis of $\mathrm{Na}^{+}$and $\mathrm{K}^{+}$ (PND F 14.1:2:4.138-98), atomic absorption spectrometry was applied to analyze $\mathrm{Ca}^{2+}$ and $\mathrm{Mg}^{2+}(\mathrm{PND} F$ 14.1: 2:4.137-98), turbidimetric method was used to measure $\mathrm{SO}_{4}{ }^{2-}$ (PND F 14.1:2.159-2000), mercury method was applied to study $\mathrm{Cl}^{-}$(PND F 14.1:2.111-97), and titrimetric method was employed in the analysis of $\mathrm{HCO}_{3}^{-}$ (GOST 31957-2012 (A.2).

The hydrochemical water type was determined according to the Kurlov's classification [27].

\section{Results}

Hydrochemical characteristic of overlying water

In all overlying water samples, taken throughout the Bratsk reservoir, the anions were dominated by $\mathrm{HCO}_{3}{ }^{-}$, followed by $\mathrm{SO}_{4}{ }^{2-}$ and $\mathrm{Cl}^{-}$. The cationic composition of water samples was dominated with $\mathrm{Ca}^{2+}$, followed by $\mathrm{Mg}^{2+}, \mathrm{Na}^{+}, \mathrm{K}^{+}$. The overlying water was low-mineralized (TDS from 101.2 to $127.7 \mathrm{mg} \mathrm{L}^{-1}$ ); $\mathrm{pH}$ referred to water being either neutral or slightly alkaline ( $\mathrm{pH}$ from 7.41 to 8.49 ).

The results reveal the following variations of major ions in the overlying water of the channel part: $\mathrm{HCO}_{3}{ }^{-}$from 66.3 to $83.0 \mathrm{mg} \mathrm{L}^{-1}, \mathrm{Cl}^{-}$from 0.9 to $4.5 \mathrm{mg} \mathrm{L}^{-1}, \mathrm{SO}_{4}{ }^{2-}$ from 7.8 up to $13.7 \mathrm{~L}^{-1}, \mathrm{Ca}^{2+}$ from 17.6 to $22.8 \mathrm{mg} \mathrm{L}^{-1}$, $\mathrm{Mg}^{2+}$ from 3.3 to $4.5 \mathrm{mg} \mathrm{L}^{-1}, \mathrm{Na}^{+}$from 2.4 to $5.1 \mathrm{mg} \mathrm{L}^{-1}, \mathrm{~K}^{+}$from 0.9 to $1.1 \mathrm{mg} \mathrm{L}^{-1}$ (Fig. 2). The concentrations of the major ions in the overlying water taken from the Bratsk reservoir were found to be similar to those from Lake Baikal (Table 2). At the same time, the reservoir samples had increased $\mathrm{Cl}^{-}$and $\mathrm{SO}_{4}{ }^{2-}$ concentrations (Fig. 2). Note, higher $\mathrm{Cl}^{-}, \mathrm{SO}_{4}{ }^{2-}$ and $\mathrm{Na}^{+}$levels were found in the Angara River before its damming [33]. Higher concentrations of those ions can be explained by the distribution of the Cambrian deposits, occurring downstream of Usolie-Sibirskoe town (Fig. 1).

Major ion concentrations were increased in the vicinity of Usolie-Sibirskoe town (10-20 km) (Fig. 2). The concentrations of anions and cations were even much higher on the left bank of the reservoir close to UsolieSibirskoe town due to the supply of wastewater enriched in $\mathrm{Cl}^{-}, \mathrm{SO}_{4}{ }^{2-}, \mathrm{Na}^{+}, \mathrm{Ca}^{2+}$ and $\mathrm{Mg}^{2+}$ [17] (Table 3). 
Table 2. Comparison of major ion concentrations $\left(\mathrm{mg} \mathrm{L}^{-1}\right)$ in overlying and pore waters of Bratsk reservoirs and other reservoirs.

\begin{tabular}{|c|c|c|c|c|c|c|c|c|c|}
\hline & & $\mathrm{HCO}_{3}^{-}$ & $\mathrm{Cl}^{-}$ & $\mathrm{SO}_{4}{ }^{2-}$ & $\mathrm{Ca}^{2+}$ & $\mathrm{Mg}^{2+}$ & $\mathrm{Na}^{+}$ & $\mathrm{K}^{+}$ & References \\
\hline \multirow[t]{5}{*}{ Bratsk reservoir } & $\begin{array}{l}\text { Overlying } \\
\text { water }\end{array}$ & 71.9 & 3.0 & 11.3 & 19.8 & 3.9 & 4.0 & 1.0 & \multirow[t]{5}{*}{ This study } \\
\hline & $\begin{array}{l}\text { Pore } \\
\text { water }\end{array}$ & $\begin{array}{l}31.7- \\
497.7^{a}\end{array}$ & $\begin{array}{l}2.9- \\
303.9\end{array}$ & $\begin{array}{l}12.7- \\
1022.0\end{array}$ & $\begin{array}{l}26.0- \\
522.0\end{array}$ & $\begin{array}{l}5.1- \\
68.3\end{array}$ & $\begin{array}{l}7.7- \\
183.0\end{array}$ & $\begin{array}{l}2.1- \\
11.1\end{array}$ & \\
\hline & $S D^{b}$ & 113.3 & 80.0 & 248.8 & 99.1 & 17.6 & 50.4 & 1.9 & \\
\hline & Soil & $\begin{array}{l}38.1- \\
370.9\end{array}$ & $\begin{array}{l}4.1- \\
285.6\end{array}$ & $\begin{array}{l}54.0- \\
2871.0\end{array}$ & $\begin{array}{l}35.4- \\
708.1\end{array}$ & $\begin{array}{l}7.5- \\
286.2\end{array}$ & $\begin{array}{l}10.1- \\
465.0\end{array}$ & $\begin{array}{l}1.6- \\
14.0\end{array}$ & \\
\hline & SD & 109.3 & 100.4 & 1158.0 & 289.7 & 105.5 & 179.7 & 4.1 & \\
\hline \multirow{2}{*}{$\begin{array}{l}\text { Ivan'kovskoe } \\
\text { reservoir, } \\
\text { Russia }\end{array}$} & $\begin{array}{l}\text { Overlying } \\
\text { water }\end{array}$ & 165 & 7 & 13 & 52.4 & 12.4 & 10.6 & & [28] \\
\hline & $\begin{array}{l}\text { Pore } \\
\text { water }\end{array}$ & $\begin{array}{l}140- \\
512\end{array}$ & $\begin{array}{l}14- \\
28\end{array}$ & $6-57$ & $\begin{array}{l}55- \\
131\end{array}$ & $\begin{array}{l}11- \\
22\end{array}$ & $5-21$ & $\begin{array}{l}3- \\
12\end{array}$ & [29] \\
\hline \multirow[t]{2}{*}{$\begin{array}{l}\text { Vyshnevolotsky } \\
\text { reservoir }\end{array}$} & $\begin{array}{l}\text { Overlying } \\
\text { water }\end{array}$ & - & $<3.5$ & $<15$ & - & - & - & - & \multirow[t]{2}{*}{ [30] } \\
\hline & $\begin{array}{l}\text { Pore } \\
\text { water }\end{array}$ & $\begin{array}{l}73- \\
298\end{array}$ & $\begin{array}{l}12- \\
18\end{array}$ & $1-15$ & $\begin{array}{l}24- \\
84\end{array}$ & $2-15$ & $1-26$ & - & \\
\hline \multirow[t]{2}{*}{ Lake Baikal } & $\begin{array}{l}\text { Overlying } \\
\text { water }\end{array}$ & 65.1 & 0.5 & 5.3 & 16.0 & 3.0 & 3.4 & 1.0 & [31] \\
\hline & $\begin{array}{l}\text { Pore } \\
\text { water }\end{array}$ & $<150$ & $<2$ & $<9$ & $<28$ & $<4$ & $<5$ & $<1$ & [32] \\
\hline
\end{tabular}

a - minimum value-maximum value; ${ }^{b}$ - standard deviation

Table 3. Major ion concentrations $\left(\mathrm{mg} \mathrm{L}^{-1}\right)$ in overlying water, left bank of the Bratsk reservoir, Usolie-Sibirskoe industrial zone.

\begin{tabular}{|llllllll|}
\hline Sampling site & $\mathrm{HCO}_{3}^{-}$ & $\mathrm{Cl}^{-}$ & $\mathrm{SO}_{4}{ }^{2-}$ & $\mathrm{Ca}^{2+}$ & $\mathrm{Mg}^{2+}$ & $\mathrm{Na}^{+}$ & $\mathrm{K}^{+}$ \\
\hline Wastewater intake area & 87.4 & 17.99 & 15.4 & 25.3 & 5.3 & 11.6 & 0.93 \\
\hline $1.5 \mathrm{~km}$ downstream of wastewater intake area & 84.4 & 8.82 & 13.5 & 24.3 & 5.0 & 6.9 & 1.05 \\
\hline $5 \mathrm{~km}$ downstream of wastewater intake area & 96.1 & 4.93 & 10.1 & 25.9 & 5.0 & 4.3 & 0.96 \\
\hline
\end{tabular}

Hydrochemical characterization of pore water in sediment 
The concentrations of major ions in the pore water samples taken from bottom sediments and subaqueous soils of the Bratsk reservoir are shown in Figs. 3, 4. Significant spatial variations were observed with respect to mineralization: the pore water mineralization varied from 165.9 to $2073.0 \mathrm{mg} \mathrm{L}^{-1}$ in bottom sediments, and from 196.3 to $4608.1 \mathrm{mg} \mathrm{L}^{-1}$ in soils. The $\mathrm{pH}$ value varied from slightly acidic (6.33) to slightly alkaline (7.88). In bottom sediments, Eh values ranged from -73 to -346 , decreasing, at most sampling sites, with depth. In subaqueous soils, Eh values changed from -145 to -289 .

Table 2 illustrates significant variability in concentrations of $\mathrm{Cl}^{-}, \mathrm{SO}_{4}{ }^{2-}, \mathrm{Ca}^{2+}, \mathrm{Mg}^{2+}, \mathrm{Na}^{+}$ions in the pore water samples, which is indicated by high standard deviation. Note, that the variations in the ionic composition were observed both across the water area and along the sediment depth profile (Figs. 3, 4).

Figures 3, 4 show that the sediment pore water can be distinguished in terms of predominant anions. In pore water samples, collected from sedimentary cores at B-2, B-5 locations and the uppermost part of B-4 and B-6 cores, $\mathrm{HCO}_{3}{ }^{-}$was a dominant anion. Moreover, except for the second layer in the sediment core at $\mathrm{B}-2 \mathrm{site}, \mathrm{SO}_{4}{ }^{2-}$ levels were higher relative to $\mathrm{Cl}^{-}$. The results revealed, that in the most pore water samples (B-1, B-3, B-7, Z-1, Z3, Z-4 sediment cores and bottom layers of B-4, B- 6 and B-8 cores), the anions were dominated by $\mathrm{SO}_{4}{ }^{2-}$. The samples collected from the second and third layers of B-1 and B-3 cores had higher $\mathrm{Cl}^{-}$concentrations in relation to $\mathrm{HCO}_{3}{ }^{-}$, while the samples from the remaining sediment cores hold higher $\mathrm{HCO}_{3}{ }^{-}$. It is worth noting the pore water samples from the upper sediment layer at $\mathrm{B}-8$ location, whose $\mathrm{HCO}_{3}{ }^{-}$and $\mathrm{SO}_{4}{ }^{2-}$ concentrations were almost similar, but $\mathrm{Cl}^{-}$level was relatively low. None of the data pointed to $\mathrm{Cl}^{-}$dominated pore water. However, by the concentration of chloride ion, pore water samples can be divided into two categories: the samples with $\mathrm{Cl}^{-}$ levels ranging from 2.9 to $15.3 \mathrm{mg} \mathrm{L}^{-1}$ (B-4, B-5, B-6, B-7, B-8, Z-4 and upper layer of B-2) and the ones whose chloride ion concentrations were in the range between 30.6 and $303.9 \mathrm{mg} \mathrm{L}^{-1}(\mathrm{~B}-1, \mathrm{~B}-3, \mathrm{Z}-2, \mathrm{Z}-3)$.

In all pore water samples, $\mathrm{Ca}^{2+}$ was a dominant cation. The $\mathrm{Mg}^{2+}$ and $\mathrm{Na}^{+}$concentrations were found to be almost similar amongst pore water samples from B-4, B-7, Z-3, upper layer of B-2, B-6, B-8, Z-1, Z-4 and bottom layer of B-2. In samples throughout B-1, B-3, Z-2 cores as well as from B-2 middle layers, total concentrations of major ions decreased as follows $\mathrm{Na}^{+}>\mathrm{Mg}^{2+}>\mathrm{K}^{+}$, while in samples from $\mathrm{B}-5$ and bottom layers of $\mathrm{B}-6, \mathrm{~B}-8, \mathrm{Z}-1$, $\mathrm{Z}-4$ the correlation between those ions followed the order $\mathrm{Mg}^{2+}>\mathrm{Na}^{+}>\mathrm{K}^{+}$.

In subaqueous soil pore water samples, there was either an increase (B-5, B-7, Z-1, Z-2, Z-3) or a decrease (B-8, Z4 ) in the concentrations of major ions in relation to the sediment pore water. In the subaqueous soil pore water samples from B-5, B-8, Z-1, Z-3 locations, the concentrations of each anion decreased in the following order $\mathrm{SO}_{4}{ }^{2-}>\mathrm{HCO}_{3}{ }^{-}>\mathrm{Cl}^{-}$; in samples from Z-2 site, anion concentrations followed the sequence $\mathrm{SO}_{4}{ }^{2-}>\mathrm{Cl}^{-}>\mathrm{HCO}_{3}{ }^{-}$and in those from B-7 and Z-4 locations, the correlation between the anions was as follows $\mathrm{HCO}_{3}{ }^{-}>\mathrm{SO}_{4}{ }^{2-}>\mathrm{Cl}^{-}$. Similar to the sediment pore water, the soil pore water was dominated by $\mathrm{Ca}^{2+}$. In soil pore water samples from B-7, B-8, Z-2 and Z-3 sites, the concentrations of major ions followed the sequence $\mathrm{Na}^{+}>\mathrm{Mg}^{2+}>\mathrm{K}^{+}$, while in samples at B-5, Z-1 and Z-4 sites, these concentrations were $\mathrm{Mg}^{2+}>\mathrm{Na}^{+}>\mathrm{K}^{+}$.

\section{Discussion}


The results reveal that only minimum $\mathrm{Cl}^{-}$concentration in sediment pore water in the Bratsk reservoir was similar to its average content in the overlying water (Table 2). In pore water samples, minimum concentrations of $\mathrm{HCO}_{3}$ are lower and those of $\mathrm{SO}_{4}{ }^{2-}, \mathrm{Ca}^{2+}, \mathrm{Na}^{+}$and $\mathrm{K}^{+}$are higher in relation to the overlying water. Maximum concentrations of major ions in the pore water were found to be higher as compared with the overlying water as follows: $\mathrm{HCO}_{3}{ }^{-}$in 7 times, $\mathrm{K}^{+}, \mathrm{Ca}^{2+}, \mathrm{Mg}^{2+}$ - in 11-26 times, $\mathrm{SO}_{4}{ }^{2-}, \mathrm{Cl}^{-}, \mathrm{Na}^{+}-46-101$ times. Therefore, the results indicate that variations in major ion concentrations between the pore and overlying water of the Bratsk reservoir are much greater than those obtained for the Ivan'kovskoe, Vyshnevolotsky reservoirs and Lake Baikal.

In contrast to surface water, pore waters typically have low dynamic characteristics due to slow water exchange. It helped identifying the factors affecting the accumulation of chemical elements in the sediment pore water. Variations in ion concentrations between the overlying and pore water samples, combined with element concentrations in sediment pore water along the depth profiles indicate that, the chemical constituents of pore water in the Bratsk reservoir are affected by a number of factors discussed below.

\section{Overlying water of reservoir}

By the studies, held earlier for different water reservoirs, it has been demonstrated, that the interaction with the overlying water affects the pore water chemistry. In the Caspian Sea, Cl-concentrations determined in the pore and overlying waters were found to be similar and be dependent on locations [34]. In the freshwater-saltwater transition zone, exemplified by the Yenisei River - Kara Sea profile, the pore water of the uppermost sediment layers exhibit a regular increase in the $\mathrm{Cl}^{-}$concentration along the river mouth-open sea gradient [35]. Since Lake Baikal, provides the major portion of the surface water to the Angara cascade reservoirs, the comparison of the Bratsk reservoir with the lake seems to be most appropriate. Earlier studies of bottom sediments from the pelagic zone of Lake Baikal, characterized by regular sedimentation rates [32], demonstrated that similar to the lake waters, low-mineralized pore waters of Lake Baikal were dominated by calcium bicarbonate.

In the Bratsk Reservoir, at initial stages of sedimentation, the poorly mineralized overlying water directly affected the pore water chemistry. However, our results show significant variations in chemical compositions of pore and overlying water with regard to major ions after 50 years of reservoir operation (Table 2). With regard to major ion composition, only the pore water, taken from upper part of B-4 sediment core with the mineralization of $169 \mathrm{mg}$

$\mathrm{L}^{-1}$ was similar to the overlying water. This similarity in the ionic composition suggests the intensified exchange between the pore and overlying water.

Since the Bratsk reservoir is a reservoir with high technogenic impact, we analyzed a possible effect of highly mineralized wastewater of Usolie-Sibirskoe industrial zone, entering the reservoir, on the ion concentrations in the pore water. Taken together, the results gained from this study (Table 3, Fig. 2) confirm earlier conclusions [17] stating that the technogenic migration of $\mathrm{Cl}^{-}, \mathrm{SO}_{4}{ }^{2-}, \mathrm{Na}^{+}, \mathrm{Ca}^{2+}$, and $\mathrm{Mg}^{2+}$ was mostly associated with their transport along the left bank of the reservoir. The levels of these ions decreased in the overlying water, reaching the mean values at a distance of $5 \mathrm{~km}$ downstream from the wastewater discharge system. The increase of the above ion concentrations in the overlying water close to Usolie-Sibirskoe town (Fig. 2) and their further decrease suggest that the anthropogenic factors have no profound effect on the accumulation of the major ions in the sediment pore water from the locations under study. At the same time, we cannot completely exclude the impact 
of wastewater on the concentration of major ions, primarily $\mathrm{Cl}^{-}$and $\mathrm{Na}^{+}$, in the pore water due to chlor-alkali industrial activities taking place in Usolie-Sibirskoe town in the period from 1970 to 1998.

\section{Sediments of reservoir}

The terrigenous material, entering the reservoir due to the destruction of rocks and abrasions of shores, and transported with water flow, plays an important role in the genesis of pore water. As was shown earlier, the pore water chemistry is greatly influenced by the chemical and mineralogical composition of bottom sediments [36].

The most common rocks in the catchment area are carbonates and sulfates, including dolomites, limestones (calcite), gypsum and anhydrites [37]. In addition, terrigenous material leaching during sedimentation leads to pore water saturation with $\mathrm{Ca}^{2+}, \mathrm{Mg}^{2+}, \mathrm{HCO}_{3}{ }^{-}$and $\mathrm{SO}_{4}{ }^{2-}$.

Within the channel part, the highest $\mathrm{Ca}^{2+}, \mathrm{Mg}^{2+}$ and $\mathrm{SO}_{4}{ }^{2-}$ concentrations were recorded in the sediment pore water samples from B-1 and B-3 locations, marked by high sedimentation rates. As follows from the regional geology (Fig.1), the main component of bottom sediments from these locations is terrigenous material coming from the abrasion of shores, composed of easily eroded gypsum-carbonate rocks. Easily soluble halite crystals present in gypsum-bearing deposits saturate the pore water from these sediment cores with chloride and sodium ions (Figs.3, 4). At locations B-1, B-2, B-3, the sediment composition is greatly influenced by the Angara River and its tributaries - the Irkut, Kitoy, Belaya rivers, carrying the minerals, formed from breaking apart of sedimentary (calcite, halite, clay minerals) and igneous (quartz, feldspars, mica) rocks [38]. Though the pore water samples at B-1, B-2 and B-3 locations were produced in a single geographic zone, $\mathrm{SO}_{4}{ }^{2-}, \mathrm{Ca}^{2+}$ concentrations and the pore water mineralization at B-2 were lower, which might result from a higher proportion of quartz, feldspars and clay minerals (alumosilicates and silicates) at B-2 in relation to B-1 and B-3 sites.

In the studied pore water samples, the major ions showed maxima in the bays of Osa, Unga and Tal'kino (Figs. 3 , 4). At locations Z-1 and Z-2, the sediments have a greater share of the material transported from the catchment areas of the Reservoir's tributaries - the Unga, Zalarinka and Osa rivers. At the confluence of the Bratsk Reservoir, gypsum-bearing rocks of the Upper Lena Formation occurring in the catchment area (Fig. 1) play a dominant role in SO4-Ca type water formation with mineralization up to $1112 \mathrm{mg} \mathrm{L}^{-1}$ in the Unga River, to $1127 \mathrm{mg} \mathrm{L}^{-1}$ in the Zalarinka River and up to $414 \mathrm{mg} \mathrm{L}^{-1}$ in the Osa River.

The mineralization of the pore water at locations B-4, B-5, B-6, B-7, B-8 and Z-4 was much lower in relation to B-1, B-2, B-3, Z-1, Z-2, Z-3 sampling sites. It, first of all, can be explained by lower sedimentation rates and, therefore, better conditions for circulation between low-mineralized overlying and pore water at B-4, B-5, B-6, B-7, B-8 and Z-4. Similar to sampling sites with higher sedimentation rates, the saturation of pore water with the major ions here is mainly due to dissolution of terrigenous material supplied into the sedimentation basin. The increase in major ion concentrations along the sediment depth profile, observed at all locations, suggests a longer interaction between the solid and liquid phases of bottom sediments.

In samples, taken from both bottom sediments and subaqueous soils, a change in pore water mineralization is symbate. The pore water samples from soils and bottom sediments at Z-1, Z-2, Z-3 locations had higher levels of major ions (Figs. 3,4) in relation to Z-4, B-7 and B-8, therefore indicating that bottom sediments generally inherited the composition of primary material of soil-forming rocks. In bays, this tendency was even more 
evident, as the hydrodynamic conditions of a bay favored the deposition of a larger portion of weathering products within its water area. Accumulation of bottom sediments at Z-1 and Z-2 locations was greatly influenced by the sulfate karst formation, in which displacements occurred along the clay interlayer formed at the contact between gypsum-anhydrite rocks and layers of limestones and gypsum-bearing dolomites [39]. The karst processes are particularly intense in the Osa bay [40]. In the Bratsk reservoir, the intense karst-landslide deformations under water level changes is one of main factors triggering the accumulation of the terrigenous sulfate formation in bottom sediments.

The leaching processes are studied using scatter plots, showing the enrichment of water with chemical elements due to the water-rock interaction [41]. The dominant reaction, occurring in the pore water- bottom sediment system, is demonstrated by a scatter plot between $\left(\mathrm{Ca}^{2+}+\mathrm{Mg}^{2+}\right)$ vs $\left(\mathrm{SO}_{4}{ }^{2-}+\mathrm{HCO}_{3}{ }^{-}\right)$(Fig. $\left.5 \mathrm{a}\right)$ showing the dissolution of calcite, dolomite, anhydrite and gypsum. Most pore water samples occur along the 1:1 equiline (Fig. 5a). Moreover, if ion exchange is the dominant process, the data points of the plot tend to shift to the right due to the excess of $\mathrm{HCO}_{3}{ }^{-}+\mathrm{SO}_{4}{ }^{2-}$ over $\mathrm{Ca}^{2+}+\mathrm{Mg}^{2+}$. However, if the dominant process is the reverse ion exchange, the points are shifted to the left [42].

Figure $5 \mathrm{~b}$ shows that the dissolution of carbonate rocks was not the major process that influenced the pore

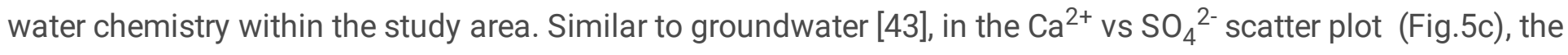
majority of points followed close to $1: 1$ equiline $\left(\mathrm{Ca}^{2+}=\mathrm{SO}_{4}{ }^{2-}\right)$, indicating that dissolutions of gypsum and anhydrite were involved into geochemical processes. The points, corresponding to pore water samples, which occur above 1:1 equiline, show that dissolutions of these minerals should occur, while excess of calcium indicates an additional geochemical process [44]. In the Bratsk reservoir, this additional process included, first of all, dissolution of carbonates followed by the cation exchange, when the alkali and alkaline earth metals $\mathrm{Na}^{+}$, $\mathrm{K}^{+}$and $\mathrm{Mg}^{2+}$ passed into the absorbing complex of the sediment and displaced $\mathrm{Ca}^{2+}$ from this complex, leading to the increase of calcium levels in pore water.

\section{Groundwater}

As shown above, the increase in major ion concentrations, primarily $\mathrm{SO}_{4}{ }^{2-}$ and $\mathrm{Ca}^{2+}$, in the pore water in relation to overlying water can be attributed to leaching processes. However, the increase in $\mathrm{Cl}^{-}$and $\mathrm{Na}^{+}$concentrations in the pore water samples at B-1, B-3 and Z-2 locations, could not only be explained by the occurrence of halite in the terrigenous material as $\mathrm{NaCl}$ was readily dissolved in the Bratsk reservoir due to a huge amount of overlying water. The water migration coefficients of $\mathrm{Cl}^{-}$and $\mathrm{Na}^{+}$in well-oxidized water of the Bratsk reservoir is very high [45]; therefore, these ions should be transported over long distances. Groundwater discharge, which is regarded as a synonym of pore water in water-saturated sediments [46, 47] could be regarded as an additional source of major ions in the pore water. Moreover, submarine groundwater discharge is an important source of nutrients to coastal areas $[46,48]$.

Compared to the Angara River and lateral inflows, groundwater discharge in the Bratsk reservoir is insignificant (not over $0.5 \mathrm{I} /\left(\mathrm{s} \cdot \mathrm{km}^{2}\right)$ [49]. The studies of hydrochemical characteristics in the Ust-llimsk and Boguchansk reservoirs, which are also parts of the Angara cascade, revealed that at several locations, the subaqueous groundwater discharge leads to the increased concentrations of major ions in the bottom water in relation to the surface one $[50,51]$. A lack of significant variations in the chemistry of surface and bottom waters within the 
Bratsk Reservoir (Fig.2) shows that the groundwater chemical composition has a minor impact on the overlying water chemistry. In the study area, there are also several tectonic dislocations, including tectonic faults, reaching the surface, and zones of tectonic fracturing [52]. In the view of Krivtsov and Sigee [53], certain combinations of meteorological and hydrological parameters could cause the groundwater percolation to the reservoir's ecosystem even through a low-permeable layer of clay deposits. Hence, percolation of more saline groundwater may be expected to affect the ionic composition of the sediment pore water. The groundwater impacts will depend on the concentration gradient and the groundwater volume.

Before filling the Bratsk reservoir, fresh, hydrocarbonate groundwater was widespread in the study area. At deeper aquifers, the groundwater composition changed into brackish sulfate [54]. After filling the reservoir, the depth to the fresh- brackish water interface was established at a smaller depth due to changes in conditions maintaining exchange between the overlying and groundwater [25]. Changes in the groundwater regime changed the pressure water discharge: in the variable backwater effect zone, the pressure water was discharged as saline springs [49], while close to the Unga Bay, sodium chloride water with mineralization of $6.2 \mathrm{~g} / \mathrm{I}$ occurred [54]. Therefore, at some locations, the concentrations of major ions in the pore water may increase due to large amounts of groundwater infiltration. This is primarily true to the southern part of the study area (from Usolie-Sibirskoe town to the Unga Bay) with sites of dome-like groundwater occurrence on the left shore of the reservoir [54]. Sodium chloride water is the most common type in the center of the dome while brackish sulfatetype water occurs mainly in dome's wings. The groundwater primarily flows upwards thus leading to Cl-SO4-NaCa chemical composition of pore water at B-1 and B-3 locations and S04-Na-Ca water type at Z-2 site (Table 4). Such a phenomenon was found for Lake Baikal as well: the hydraulic groundwater-pore water interaction was discovered in the Selenga shallow water [55]. At the same time, similar to the Bratsk reservoir, the subaqueous groundwater discharge appears not to affect the mineralization of the bottom water.

The concentrations of $\mathrm{SO}_{4}{ }^{2-}, \mathrm{Cl}^{-}$and $\mathrm{Na}^{+}$in the pore water decreased toward the top of the sediment (Fig.3), therefore suggesting the groundwater penetration. The bottom sediment layers at B-5, Z-1, Z-2, Z-4 sampling sites, contained the soils demonstrating higher permeability and an ability to accumulate many chemical elements as opposed to bottom sediments. Low dynamic characteristics of pore water and low filtration coefficients of clayey rock formations, dominant in the upper part of the sediment cores, are the main factors, responsible for accumulation of chemical elements brought with groundwater into the lower sediment section.

\section{Early diagenetic processes}

The early diagenetic transformations of Lake Baikal sediments were studied based on the distribution of major ions in sediment pore water [56]. It was found, that at sites with relatively calm sedimentation conditions (no faults, and groundwater infiltration), the pore water of the upper (oxidized) sediment layer contained much lower $\mathrm{HCO}_{3}{ }^{-}$concentrations than the bottom water. In the reducing sediments, $\mathrm{HCO}_{3}{ }^{-}$concentration increased due to the decay of the buried organic matter. On the contrary, the $\mathrm{SO}_{4}{ }^{2-}$ conncentration showed the maximum in the oxidized layer, decreasing along the sediment depth profile by an order of magnitude due to the bacterial sulfate reduction. In the Baikal region, a similar distribution of $\mathrm{HCO}_{3}{ }^{-}$and $\mathrm{SO}_{4}{ }^{2-}$ was found in organogenic sediments of small lakes [57]. As opposed to lakes with a longer existence period, early diagenetic transformations of sediments from the Angara cascade reservoirs, remains an insufficiently studied geochemical sector. However, the data obtained for the Bratsk reservoir show early diagenetic transformations of organic and mineral

Page $11 / 22$ 
substances brought to the bottom of the Bratsk reservoir during sedimentation. In the Bratsk reservoir, one of the early diagenesis indicators is the change in the hydrochemical composition type of the overlying water. The $\mathrm{Ca}-\mathrm{HCO} 3$ type, which was dominant in the overlying water, occurred in the pore water samples taken only from the first and second layers at B-2 location and upper layer at B-4 site (Table 4). The pore water by SO4 and HCO3-SO4 types, with exchangeable cations, mainly Ca, became more common in the Bratsk reservoir (Table 4).

Negative Eh values in pore water samples of the Bratsk Reservoir (Figs. 3, 4) indicate that the bottom sediments undergo reduced diagenetic transformations whose intensity depends on the amount of organic matter [58]. It should be noted that large amounts of organic materials were brought during the reservoir filling when 166 thousand hectares of agricultural and 135.2 thousand of forest were flooded [23]. Under reducing conditions, the most mobile labile organic matter compounds are transferred to the solution due to microbiological transformations leading to an increase of $\mathrm{HCO}_{3}{ }^{-}$contents in the pore water along the sediment depth profile.

Color stratification along the sediment depth profile is an indicator of sulfate reduction activity [59]. In the Bratsk reservoir, the redox early diagenetic processes are shown by the presence of brown-orange surface sediments, which are then replaced by dark gray sediments, indicating sulfate reduction and the formation of hydrogen sulfide derivatives. It was found that the concentrations of $\mathrm{SO}_{4}{ }^{2-}$ in pore water samples increased as the sediment depth increases thus suggesting that the sulfate reduction processes were less intensive. Yudovich and Ketris [60] showed that the poorly decomposed organic matter in anaerobic environments does not favor the processes of sulfate reduction and requires a longer presence of organic matter in anaerobic conditions. On the other hand, in such relatively young reservoir like the Bratsk, the dominant processes determining the pore water chemical composition are dissolution of detrital material and subaqueous groundwater discharge.

At initial stages of the Bratsk reservoir's operation, the subaqueous soils contained fine - grained calcite [22], a

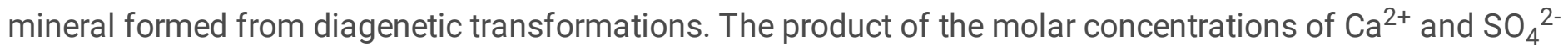
which is over $2.37 \cdot 10^{-5}$ favors the formation of $\mathrm{CaSO}_{4}$ in the solution [45]. Currently, these values in the pore water of Bratsk reservoir range from $3.5 \cdot 10^{-5}$ to $1389.3 \cdot 10^{-5}$, indicating the formation of authigenic minerals.

Table 4. Pore water classification, Bratsk reservoir. 


\begin{tabular}{|c|c|c|c|c|c|c|c|c|}
\hline \multicolumn{2}{|c|}{ Sampling site } & \multirow[t]{2}{*}{ Type of water ${ }^{a}$} & \multicolumn{2}{|c|}{ Sampling site } & \multirow[t]{2}{*}{ Type of water } & \multicolumn{2}{|c|}{ Sampling site } & \multirow[t]{2}{*}{ Type of water } \\
\hline \multirow[t]{3}{*}{ B-1 } & $0-8 \mathrm{~cm}$ & & \multirow[t]{2}{*}{ B-4 } & $0-10 \mathrm{~cm}$ & & \multirow[t]{3}{*}{ Z-1 } & $0-13 \mathrm{~cm}$ & \\
\hline & $8-19 \mathrm{~cm}$ & & & $10-20 \mathrm{~cm}$ & & & $13-26 \mathrm{~cm}$ & \\
\hline & $19-30 \mathrm{~cm}$ & & \multirow[t]{2}{*}{ B-5 } & $0-17 \mathrm{~cm}$ & & & $26-46 \mathrm{~cm}$ & \\
\hline \multirow[t]{5}{*}{ B-2 } & $0-8 \mathrm{~cm}$ & & & $17-34 \mathrm{~cm}$ & & \multirow[t]{3}{*}{$\mathrm{Z}-2$} & $0-16 \mathrm{~cm}$ & \\
\hline & $8-19 \mathrm{~cm}$ & & \multirow[t]{2}{*}{ B-6 } & $0-8 \mathrm{~cm}$ & & & $16-32 \mathrm{~cm}$ & \\
\hline & $19-30 \mathrm{~cm}$ & & & $8-17 \mathrm{~cm}$ & & & $32-42 \mathrm{~cm}$ & \\
\hline & $30-41 \mathrm{~cm}$ & & \multirow[t]{3}{*}{ B-7 } & $0-7 \mathrm{~cm}$ & & \multirow[t]{4}{*}{ Z-3 } & $0-20$ & \\
\hline & & & & & & & $\mathrm{cm}$ & \\
\hline \multirow[t]{5}{*}{ B-3 } & $0-8 \mathrm{~cm}$ & & & $7-16 \mathrm{~cm}$ & & & $20-45 \mathrm{~cm}$ & \\
\hline & $8-21 \mathrm{~cm}$ & & \multirow[t]{4}{*}{ B-8 } & $0-6 \mathrm{~cm}$ & & & $45-70 \mathrm{~cm}$ & \\
\hline & $21-42 \mathrm{~cm}$ & & & $6-14 \mathrm{~cm}$ & & \multirow[t]{3}{*}{ Z-4 } & $0-8 \mathrm{~cm}$ & \\
\hline & $42-64 \mathrm{~cm}$ & & & $14-32 \mathrm{~cm}$ & & & $8-16 \mathrm{~cm}$ & \\
\hline & $64-86 \mathrm{~cm}$ & & & & & & $16-24 \mathrm{~cm}$ & \\
\hline
\end{tabular}

a $-\mathrm{M}$ - mineralization $\left(\mathrm{mgL}^{-1}\right)$; the number next to the ion mean the ion content $\left(\% \mathrm{mEq} \mathrm{L}{ }^{-1}\right)$ of the total number of cations and anions corresponding to $100 \%$. The type of water is determined by ions with the content more than $12 \%$.

\section{Conclusion}

In the Bratsk reservoir, the chemical composition of pore water shows significant variations both across the water area and along the sediment depth profile. It was found, that the initial pore water composition was primarily determined by $\mathrm{HCO} 3-\mathrm{Ca}$-type overlying water, which during sedimentation process and depending on sampling site, changed to $\mathrm{SO} 4, \mathrm{SO} 4-\mathrm{HCO} 3, \mathrm{HCO}-\mathrm{SO} 4, \mathrm{HCO} 3-\mathrm{Cl}-\mathrm{SO} 4$-water types with exchangeable cations, mainly $\mathrm{Ca}$. The pore water mineralization of cored sediments displays a clear increasing trend with depth, which can be explained by the presence of dissolving sulfate and carbonate salts in terrigenous sediments, thickness of sediments and a longer interaction of the pore water and bottom sediments. At the same time, some of pore waters may have a complex genesis associated with subaqueous groundwater discharge, which is evidenced by higher $\mathrm{Cl}^{-}$and $\mathrm{Na}^{+}$concentrations in pore water.

The change in the redox potential observed in the pore water is the main indicator of early-diagenetic transformations taking place in bottom sediments, and a dominant factor that leads to drastic changes in the initial chemical composition of pore waters. This is the first study aimed at determining the factors affecting the pore water chemistry in the Bratsk reservoir. In future, the studies aimed at microbial sulfate reduction processes, distribution patterns and forms of $\mathrm{Fe}$ and $\mathrm{Mn}$ in the solid phase and pore waters, their mineral composition will result in a more detailed approach to describing geochemical cycles of elements in a large reservoir. 


\section{Declarations}

\section{Acknowledgments}

The work was performed by the governmental assignment in terms of Project IX.127.1.4. (0350-2019-0005) and was supported by the project "Fundamentals, methods and technologies for digital monitoring and forecasting of the environmental situation on the Baikal natural territory", No. 13.1902.21.0033. The authors are grateful to Khomutova M. Yu. for editing the English version of the text.

\section{Authors' contributions.}

All authors contributed to the work on the manuscript. Material preparation, data collection and analysis were performed by Poletaeva V.I., Pastukhov M.V. and Tirskikh E.N. The first draft of the manuscript was written by Poletaeva V.I. and all authors commented on previous versions of the manuscript. All authors read and approved the final manuscript.

Competing Interests: The authors declare no competing interests.

\section{References}

1. Wildi, W. Environmental hazards of dams and reservoirs. NEAR Curriculum in Natural Environmental Science. Terre et Environment 88, 187-197 (2010).

2. Dević, G. Environmental Impacts of Reservoirs In: Environmental Indicators (eds. Armon, R, Hänninen, 0) 561-575 (Springer, Dordrecht, 2015).

3. Omwoma, S. et al. Comparative exposomics of persistent organic pollutants (PCBs, OCPs, MCCPs and SCCPs) and polycyclic aromatic hydrocarbons (PAHs) in Lake Victoria (Africa) and Three Gorges Reservoir (China). Science of the Total Environment 695, 133789 (2019).

4. Varol, M. Environmental, ecological and health risks of trace metals in sediments of alarge reservoir on the Euphrates River (Turkey). Environmental Research 187, 109664 (2020).

5. Zakonnonov, V.V., Poddubnyi, S.A., Zakonnova, A.V. \& Kas'yanova, V.V. Sedimentation in variable-backwater zones of Volga chain reservoirs. Water Resources 37(4), 462-470 (2010).

6. Savkin, V.M., Dvurechenskaya, S.Y. \& Kondakova, O.V. Impact of the Novosibirsk reservoir on the formation of hydrological and hydrochemical regime of the upper Ob river in the regulated area. Water and Ecology 25(1), 51-62 (2020).

7. Hahn, J. et al. Impacts of dam draining on the mobility of heavy metals and arsenic in water and basin bottom sediments of three studied dams in Germany. Science of the Total Environment 640, 1072-1081 (2018).

8. Fiket, Ž., Fiket, T., Ivanić, M., Mikac, N. \& Kniewald, G. Pore water geochemistry and diagenesis of estuary sediments-an example of the Zrmanja River estuary (Adriatic coast, Croatia). Journal of Soils and Sediments 19, 2048-2060 (2019).

9. Abukova, L.A. \& Abramova, O.P. Effect of pore water of fine sediments on the ecological conditions of hydrosphere under oil-and-gas technogenesis conditions. Water Resources 43(4), 668-676 (2016). 
10. Matsuyama, A. et al. Chemical characteristics of dissolved mercury in the pore water of Minamata Bay sediments. Marine Pollution Bulletin 129, 503-511 (2018).

11. Berner, R.A. Early Diagenesis: A theoretical approach. (Princeton University Press, Princeton, 1980).

12. Schulz, H.D. Quantification of early diagenesis: Dissolved constituents in marine pore water in Marine Geochemistry (eds. Schulz, H.D., Zabel, M.) 73-124 (Springer, Berlin, 2006).

13. Sala, O.E. et al. Biodiversity: Global Biodiversity Scenarios for the Year 2100. Science 287, 1770-1774 (2000).

14. Jagus, A., Khak, V., Rzêta£a, M.A. \& Rzêta£a, M. Trace elements in the bottom sediments of the Irkutsk reservoir. Ecological Chemistry and Engineering. A 19(8), 939-950 (2012).

15. Poletaeva, V.I., Pastukhov, M.V. \& Dolgikh, P.G. Geochemical characteristics of microelement distribution in surface sediments of Ust-Ilimsk Reservoir. IOP Conf. Series: Earth and Environmental Science 321, 012042 (2019).

16. Koval, P.V. et al. Anthropogenic component and balance of mercury in ecosystem of the Bratsk hydropower reservoir. Doklady Earth Sciences 388(2), 225-227 (2003).

17. Alieva, V.I. \& Pastukhov, M.V. Hydrochemical characteristic of the Angara River in the influence area of the Usolie industrial center [n Russian]. Geography and natural resources 1, 68-73 (2012).

18. Poletaeva, V.I., Pastukhov, M.V., Zagorulko, N.A. \& Belogolova G.A. Changes in Water hydrochemistry in bays of the Bratsk Reservoir caused by forest harvesting operations. Water Resources 45(3), 369-378 (2018).

19. Pastukhov, M.V, Poletaeva, V.I. \& Tirskikh, E.N. Long-term dynamics of mercury pollution of the Bratsk reservoir bottom sediments, Baikal region, Russia. IOP Conf. Series: Earth and Environmental Science 321, 012041 (2019).

20. Rzetala, M., Babicheva, V.A. \& Rzetala, M.A. Composition and physico-chemical properties of bottom sediments in the southern part of the Bratsk Reservoir (Russia). Scientific Reports 9, 12790 (2019).

21. Perrot, V. et al. Tracing Sources and Bioaccumulation of Mercury in Fish of Lake Baikal - Angara River Using Hg Isotopic Composition. Environmental Science and Technology 44(21), 8030-8037 (2010).

22. Seryshev, V.A. Subaquatic soil diagenesis and classification of aquatic soils [in Russian] (IGU, Irkutsk, 2017).

23. Ivanov,N. Hydropower hangars and the natural environment [in Russian]. (Nauka, Novosibirsk, 1991)

24. Karnaukhova, G.A. Sedimentation system of the Angara river after regulation of its flow. Doklady Earth Sciences 413(3), 351-353 (2007).

25. Ovchinnikov, G. I., Pavlov, S. C. \& Trzhtsinsky, U. B. Change of geological environment in the zones of influence of the Angara-Yenisei reservoirs [in Russian]. (Nauka, Novosibirsk, 1999).

26. Karnaukhova, G.A. Belt zoning of sedimentation in the Angara cascade reservoirs. Geochemistry International 49(6), 605-617 (2011).

27. Alekin, O.A. Principles of hydrochemistry [in Russian]. (Hydrometeorologicheskoe Izdat, Leningrad, 1970).

28. Lapina, E.E. \& Chekmariova, E.A. Assessment of the current state of groundwater in coastal zone of the Ivan"kovskoye reservoir and its tributaries in winter period [in Russian]. Herald of Tver State University. Series: Geography and Geoecology 3, 45-60 (2018). 
29. Lipatnikova, O.A. et al. (2014) Features of different forms of trace elements in bottom sediments of Ivankovskoe water reservoir [in Russian]. Engineering geology. Hydrogeology. Geocryology 1, 37-48.

30. Lipatnikova, O.A. Heavy metal speciation in bottom sediments of the Vyshnevolotsky reservoir Moscow University Bulletin. Series 4. Geology 3, 46-54 (2018).

31. Domysheva, V.M. et al. Ionic Composition of Water in Lake Baikal, Its Tributaries, and the Angara River Source during the Modern Period. Russian Meteorology and Hydrology 10, 77-86 (2019).

32. Pogodaeva, T.V., Lopatina, I.N., Khlystov, O.M., Egorov, A.V. \& Zemskaya, T.I. Background composition of pore waters in Lake Baikal bottom sediments. Journal of Great Lakes Research 43, 1030-1043 (2017).

33. Bochkarev, P.F. Hydrochemistry of the rivers of eastern Siberia [in Russian]. (East Siberian publishing house, Irkutsk, 1959).

34. Brezgunov, V.S. \& Ferronsky, V.I. Macro- and microelements in the interstitial water of deep-water areas of the southern and middle Caspian Sea. Water Resources 37(6), 825-833 (2010).

35. Lein, A.Yu. et al. Biogeochemical processes of the sulfur cycle in the early stages of sediment diagenesis on the Yenisei-Kara Sea profile. Oceanology 34(5), 681-692 (1994).

36. Aleksander-Kwaterczak, U. \& Zdechlik, R. Hydrogeochemical characteristics of interstitial water and overlying water in the lacustrine environment. Environmental Earth Sciences 75, 1352 (2016).

37. Trzhtsinsky, Yu.B. Anthropogenic activation of karst in the East Siberia. Carbonates and Evaporites 17(2), 117-124 (2002).

38. Karnaukhova, G.A. \& Skovitina, T.M. Settings of the formation of mineral composition of bottom sediments in the barrier zone of the Angara River. Lithology and mineral resources 49(2), 165-176 (2014).

39. Gutareva, O.S., Kozyreva, E.A. \& Trzhtsinsky, Y.B. Karst under natural and technogenically modified conditions in southern East Siberia. Geography and natural resources 30(1), 40-46 (2009.)

40. Kaczmarek, H. et al. Impact of large water level fluctuations on geomorphological processes and their interactions in the shore zone of a dam reservoir. Journal of Great Lakes Research 42(5), 926-941 (2016).

41. Viers, J. et al. Geochemistry of Chilean Rivers Within the Central Zone: Distinguishing the Impact of Mining, Lithology and Physical Weathering. Aquatic Geochemistry 25, 27-48 (2019).

42. Fisher, R.S. \& Mullican, W.F. Hydrochemical evolution of sodium-sulfate and sodium-chloride groundwater beneath the Northern Chihuahuan Desert, Trans-Pecos, Texas, USA. Hydrogeology Journal 5, 4-16 (1997).

43. Das, B.K. \& Kaur, P. Major ion chemistry of Renuka lake and weathering processes, Sirmaur district, Himachal Pradesh, India. Journal of Environmental Geology 40, 908-917 (2001).

44. Subramani, T., Rajmohan, N. \& Elango, L. Groundwater geochemistry and identification of hydrogeochemical processes in a hard rock region, Southern India. Environmental Monitoring and Assessment 162, 123-137 (2010).

45. Perel'man, A.I. Geochemistry [in Russian]. (High school, Moscow, 1989).

46. Moore, W.S. The effect of submarine groundwater discharge on the ocean. Annual Review of Marine Science 2, 59-88 (2010).

47. O'Reilly, C., Santos, I.R., Cyronak, T., McMahon, A. \& Maher, D.T. Nitrous oxide and methane dynamics in a coral reef lagoon driven by pore water exchange: insights from automated high-frequency observations. Geophysical Research Letters 42(8), 2885-2892 (2015). 
48. Chen, X., Wang, J., Cukrov, N. \& Du, J. Porewater-derived nutrient fluxes in a coastal aquifer (Shengsi Island, China) and its implication. Estuarine. Coastal and Shelf Science 218, 204-211 (2019).

49. Shen'kman, B.M. Changes in the hydrogeological situation in the Angara river valley due to flow regulation in Problems of protecting the geological environment (for example, Eastern Siberia) [in Russian]. 103-117 (Nauka, Novosibirsk, 1993).

50. Poletaeva, V.I., Pastukhov, M.V. \& Zagorulko, N.A. Specific features of the hydrochemical regime change at the Boguchany reservoir in time of its filling. Russian Meteorology and Hydrology 7, 97-108 (2018).

51. Poletaeva, V.I., Dolgih, P.G. \& Pastuhov, M.V. Specifics of hydrochemical regime formation at the Ust-llimsk water reservoir [in Russian]. Water: chemistry and ecology 10, 11-17 (2017).

52. Seismic zoning of Eastern Siberia and its geological and geophysical foundations [in Russian] (ed. Solonenko, V.P.) (Nauka, Novosibirsk, 1997).

53. Krivtsov, V. \& Sigee, D.C. Importance of biological and abiotic factors for geochemical cycling in a freshwater eutrophic lake. Biogeochemistry 74, 205-230 (2005)

54. Pavlov, S. Kh. Hydrodynamic and hydrochemical features of the backwater zone in the upper section of the Bratsk reservoir in Regional hydrogeology and engineering geology of Eastern Siberia [in Russian] 97-104 (Nauka, Novosibirsk, 1978).

55. Mizandrontsev, I.B., Tomberg, I.V., Sorokovnikova, L.M. \& Sinyukovich, V.N. Effect of groundwater runoff on the chemical composition of the delta-front water of the Selenga river, lake Baikal. Geochemistry International 52(10), 891-897 (2014).

56. Pogodaeva, T.V. et al. Chemical composition of pore waters of bottom sediments in different Baikal basins. Russian Geology and Geophysics 48(11), 886-900 (2007).

57. Leonova, G.A. et al. Geochemistry of Diagenesis of Organogenic Sediments: An Example of Small Lakes in Southern West Siberia and Western Baikal Area. Geochemistry International 56(4), 344-361 (2018).

58. Geochemistry of diagenesis of pacific sediments (Transoceanic Profile) [in Russian] (ed. Ostroumov, E.A.) (Nauka, Moscow, 1980)

59. Rozanov, A.G., Gurskii, Y.N. \& Kokryatskaya, N.M. Composition of interstitial waters and forms of sulfur compounds in bottom sediments in the northeastern Black Sea. Lithology and Mineral Resources 52(4), 249-262 (2017).

60. Yudovich, Ya.E. \& Ketris, M.P. Geochemical indicators of lithogenesis (lithological geochemistry) [in Russian]. (Geoprint, Syltyvkar, 2011).

\section{Figures}




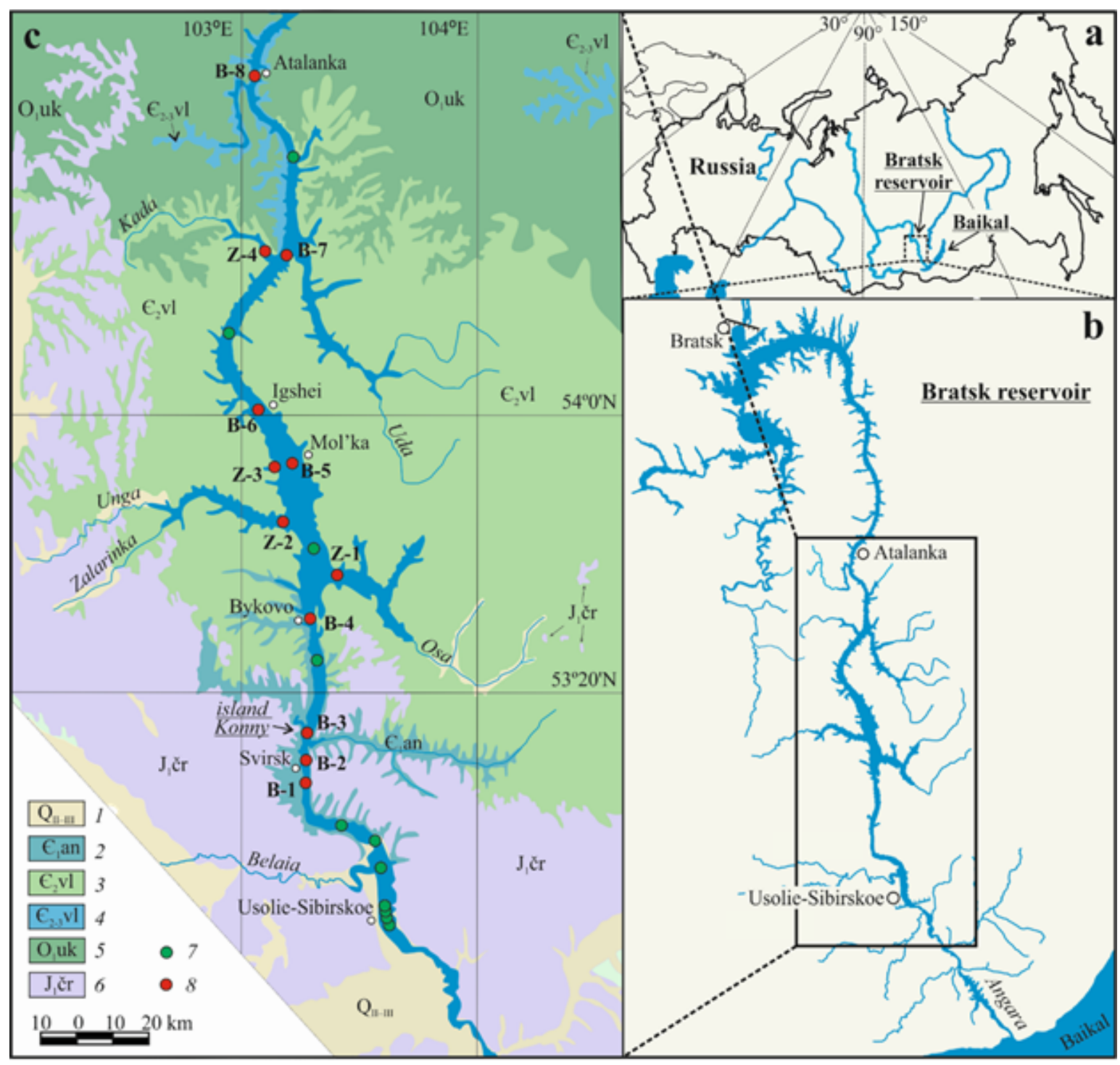

Figure 1

(a) Location of the Bratsk reservoir. (b) View of the wider study area. (c) schematic geologic map with indicated sampling locations. Legends:1c: 1 - alluvial deposits (sand, pebbles, sandy loam); 2 - Lower Cambrian Angara formation (dolomites, anhydrite-dolomites, gypsum, rock salt); 3 - Middle Cambrian Upper Lena formation (sandstones, siltstones, marls, mudstones, gypsum); 4 - Middle-Upper Cambrian Vilyu formation (sandstones, siltstones, marls); 5 - Lower Ordovician Ust-Kut formation (siltstones, mudstones, sandstones); 6 - Jurassic sediments, Cheremkhovo formation (conglomerates, sandstones, siltstones); 7 - sampling locations of overlying water; 8 -sampling locations of overlying and pore water 


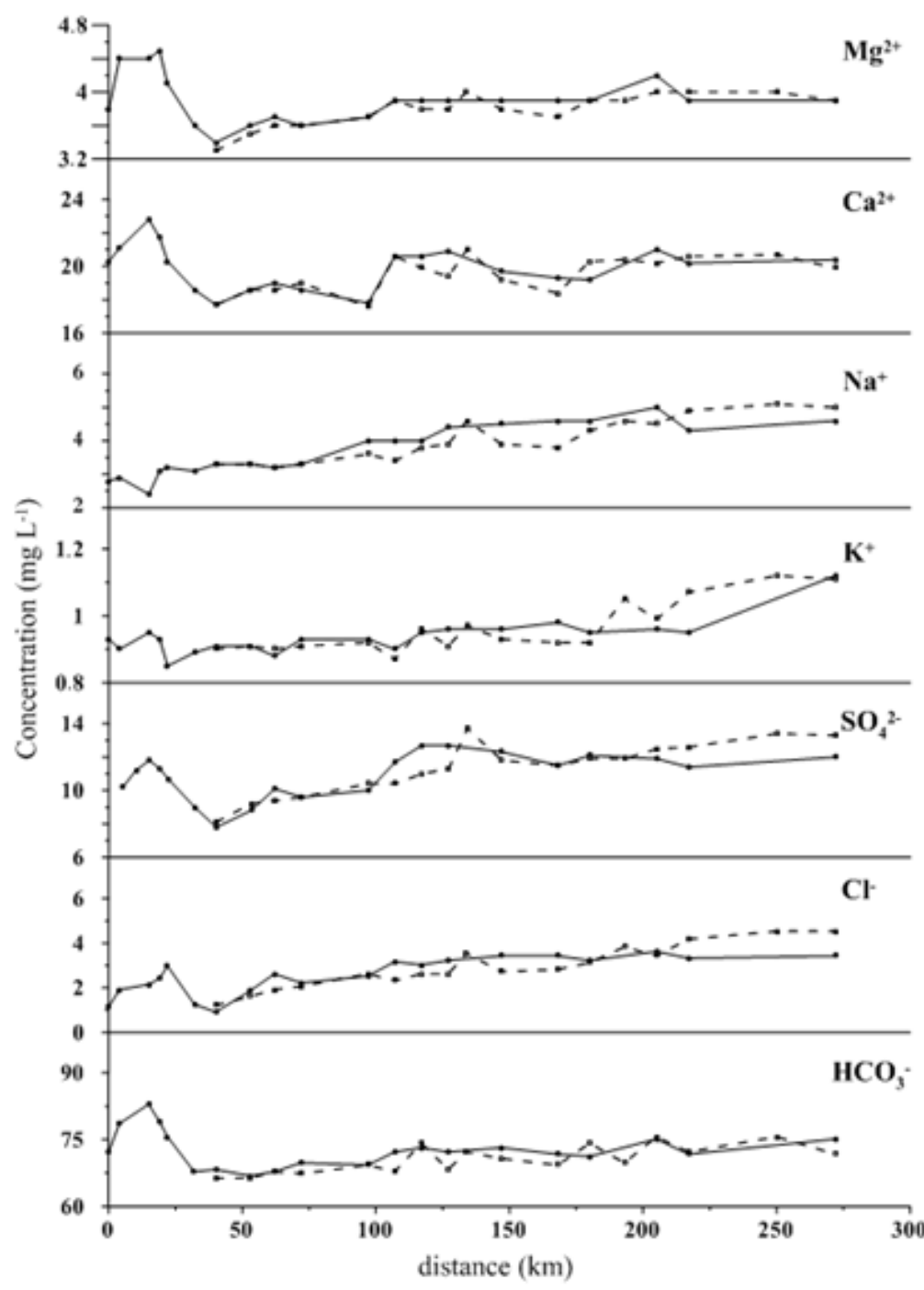

surface water

. . . . bottom water

\section{Figure 2}

Distribution of major ions (mg L-1) in overlying water of the Bratsk reservoir (from Usolie-Sibirskoe town (0 km) to Atalanka settlement (274 km). 


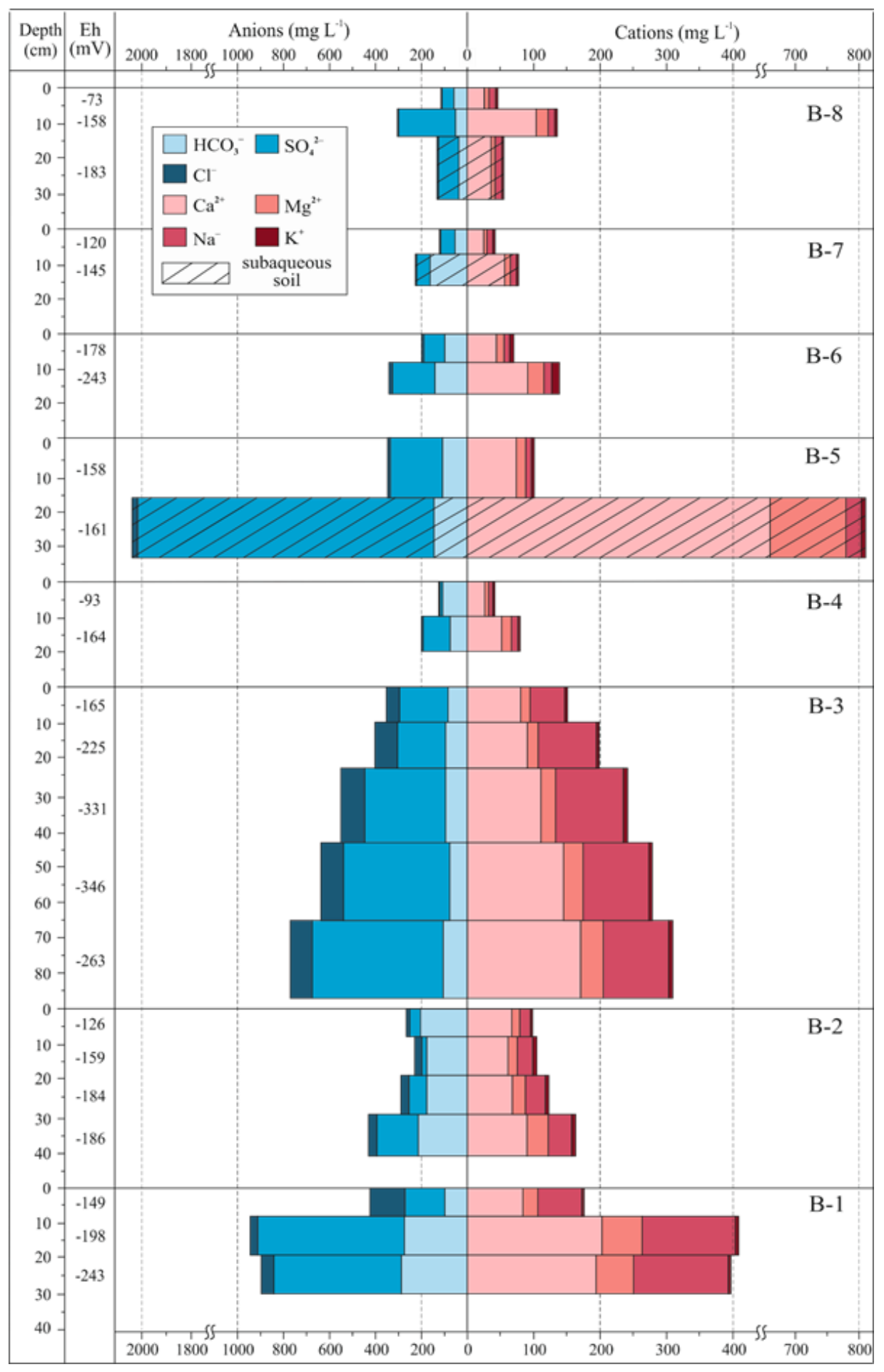

Figure 3

Major ion distributions in pore water from the channel part, Bratsk reservoir 


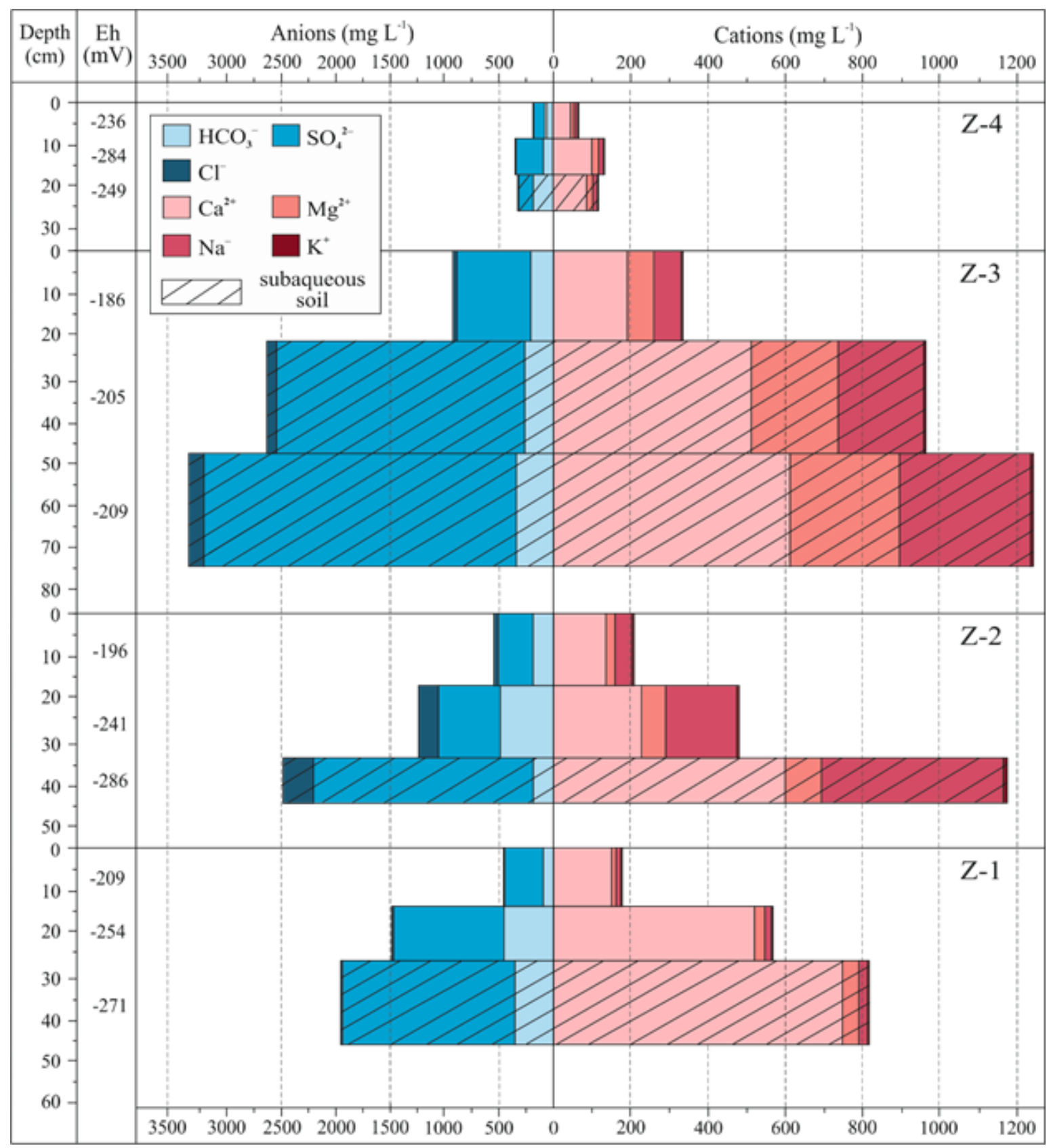

Figure 4

Major ion distributions in pore waters from bays, Bratsk reservoir 

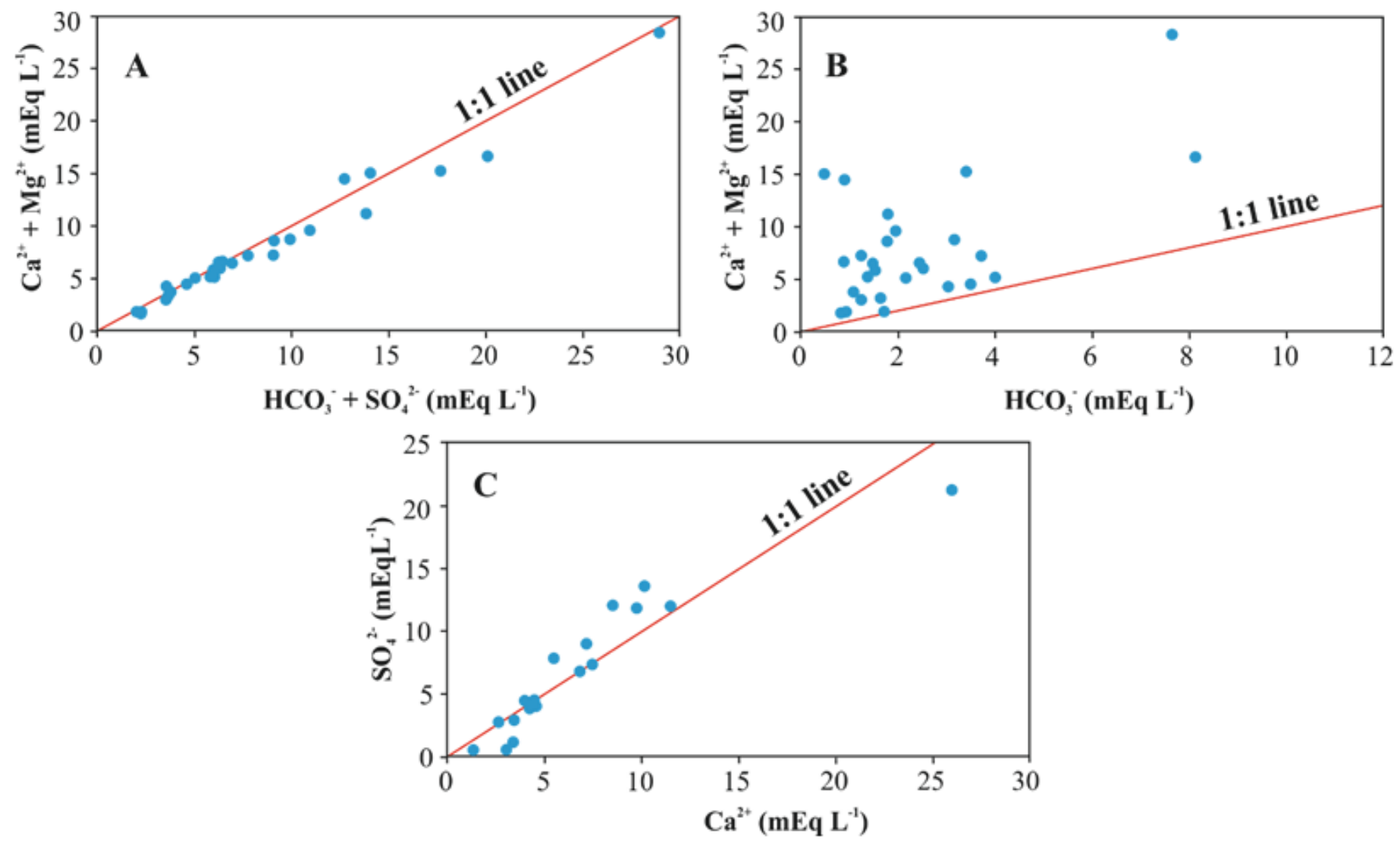

Figure 5

Distribution $\mathrm{Ca} 2++\mathrm{Mg} 2+$ vs HCO3- + SO42- (a), $\mathrm{Ca} 2++$ Mg2+ vs HCO3- (b), SO42- vs Ca2+ (c). 